\title{
Facilitating an Entrepreneurial Discovery Process for Smart Specialisation. The Case of Poland
}

\author{
Krzysztof Mieszkowski • Marcin Kardas
}

Received: 13 January 2014 / Accepted: 8 January 2015 /

Published online: 26 February 2015

(C) The Author(s) 2015. This article is published with open access at Springerlink.com

\begin{abstract}
The purpose of this paper is to study stakeholder involvement in research and innovation policy in Poland in the context of smart specialisation exercise. The article addresses the questions to what extent initiatives such as the foresight programmes, strategic research and development programmes, and sectoral research programmes facilitate the entrepreneurial discovery process for smart specialisation. The role of different groups of actors varies substantially in terms of their involvement and impact on such initiatives. The foresight and strategic research and development programmes were dominated by representatives of the research community and embody a research-oriented top-down approach. The sectoral research programmes are most closely related to the bottom-up and demand-driven approach in which the leading role is played by entrepreneurs. For this reason, they are more familiar with the conditions of the entrepreneurial discovery process. In this case, the important role is also played by the governmental agency which facilitates those processes.
\end{abstract}

Keywords Entrepreneurial discovery process $\cdot$ Smart specialisation strategy Stakeholder involvement · Priority setting $\cdot$ Research and development

\section{Introduction}

Interactions and collaboration between different groups of actors, especially entrepreneurs, researchers and users, are one of the key characteristics of entrepreneurship and innovation activities. The requirement to involve a great range of stakeholders in major policy decisions is one of the important implications for innovation policy (Martin

The views expressed are purely those of the authors and may not in any circumstances be regarded as stating an official position of the European Commission.

K. Mieszkowski $(\bowtie)$

JRC-IPTS, Seville, Spain

e-mail: krzysztof.mieszkowski@interia.pl

M. Kardas

University of Warsaw, Warsaw, Poland

e-mail: kardasek@gmail.com 
2010a). The role of different actors (agents from research, environmental and health policy) is of particular importance in the process of identifying and selecting research priorities. In recent years, these processes have become much more decentralised than the centralised decision-making processes of the older paradigms (Gassler et al. 2008). According to the OECD, diverse stakeholder involvement in priority setting is a salient trend in most countries and is undertaken in the interests of increasing transparency and to better respond to societal needs. The new approaches to decision-making processes include broad consultation with scientific experts with policy, business and community representatives (OECD 2003).

At the economic policymaking level, there is a need to have a strategic collaboration between the government and private sector in order to overcome development obstacles and make use of existing opportunities. This strategic collaboration should constitute the fundaments to a discovery process (Rodrik 2004). Stakeholder involvement within entrepreneurial discovery process is at the very centre of the smart specialisation concept. The goal of this concept is to focus limited financial and human resources on certain domains in order to develop distinctive and original areas of specialisation. These domains should be defined in studies on economic structure and on the discovery processes undertaken by enterprises and other organisations operating within this economy (Foray et al. 2011).

The entrepreneurial discovery processes became particularly important for all EU Member States. The CPR regulation for financial perspective 2014-2020 imposed on them the preconditions regarding all research and innovation investments co-financed with structural funds (in the case of Poland, it is planned to allocate about 10 billion euro for research and innovation). According to the ex-ante conditionalities for Thematic Objective 1, Member States should possess strategies for smart specialisation at national or regional level. The strategy is expected to show their vision and ways to spend the structural funds on research and innovation projects. Besides focusing national or regional resources on the limited number of priorities, this strategic framework should also strongly consider stimulation of private research and development (R\&D) investment in these fields. The documents should be developed in the process which involve a broad number of research and innovation actors like universities (and other higher education institutions), industry and social partners in an entrepreneurial discovery process (EU Regulation 1303/2013/EU). These preconditions are adjective stimulus for policymakers to organise decision-making processes in a more open, transparent and inclusive way. The task of authorities is to facilitate the processes of entrepreneurial discovery.

Despite the rich literature on the engagement of stakeholders including foresight and the growing number of publication on the smart specialisation concept, this topic still seems to be very attractive for research. This particularly concerns less advanced economies in terms of research and innovation, such as Poland. The economic and research systems in Poland have substantially evolved over the last 30 years. During this time, the governance structure and research funding system moved from the highly centralised model typical of communist countries to a model based on capitalist and market-driven rules. These changes were accompanied by the growing role of a different group of actors in research and innovation policies, especially the scientific community. In Poland, in recent years, there have been implemented many activities involving different stakeholders in these processes. Foresight programmes, strategic 
research and development programmes, and sectoral research programmes are particularly interesting for the purpose of this article.

Taking into account the above, the article examines the following question:

To what extent do the chosen initiatives facilitate the entrepreneurial discovery process for smart specialisation in Poland?

This paper reviews the literature on entrepreneurial discovery and the smart specialisation concept, priority setting and foresight exercises. Next, it presents the research settings and results from studies on the evolution of the research system in Poland and three initiatives: the foresight programmes, strategic research and development programme, and sectoral research programmes. In conclusion, the issues related to the engagement of stakeholders in priority setting are discussed, particularly from the perspective of the evolution of research systems and requirements of the smart specialisation strategy.

\section{Literature Review-Theoretical Context}

\section{Entrepreneurial Discovery}

According to D. Rodrik, there is a need to have a strategic collaboration between government and private sector in economic policy, because government does not have full information about what is happening in the economy (limited access to information about constraints and opportunities, right location and market failures). Furthermore, there is a need to overcome development obstacles and make use of existing opportunities. Business and government can learn about that together in a discovery process. The issue relates to how this process can be designed to allow the effective collaboration of private and public stakeholders. The government should cooperate in a way to avoid corruption and rent-seeking temptations. In this case, there is a need to sustain public autonomy against private interests. The other issue is the transformation of the dominant innovation development perspective from the supply side to that of the demand. The additional observation which should be considered in this process is a mechanism of transparency and accountability (Rodrik 2004).

Democratic processes involving compromise between the different actors, i.e. all actors from the research and development sector as well as representatives of civil society, are crucial from the perspective of the smart specialisation concept. This concept proposes to identify the priorities (domains of specialisation) by observing the economic structures and supporting the processes of entrepreneurial discoveries undertaken by companies and other organisations (Foray et al. 2009; Foray et al. 2011). From the perspective of the smart specialisation strategy, the term entrepreneur is considered in a broad sense and does not only refer to business enterprise. The smart specialisation process should also involve research leaders, education institutions, inventors, non-government organisations (NGOs) and societal associations. Nevertheless, the role of certain classes of players (such as researchers, suppliers, manufacturers, service providers, entrepreneurs and users) is crucial. They use their potential and resources to scan the available opportunities and identify technological and market niches for exploitation (McCann and Ortega-Argilés 2011). The above-mentioned 
actors play a key role because they match entrepreneurial knowledge about science, technology and engineering with that of the market potential and competitors. This is the whole set of inputs required for launching new activity (Foray et al. 2011).

The process of smart specialisation should be seen as the permanent discovery process which forces policy to support the never-ending learning process. This may lead to spillovers which are usually unpredictable and may also convince the actors to give up their current erroneous development approach. It could in turn lead to structural economic change by radical foundation, transition, modernisation or diversification. So, the smart specialisation process should lead to priorities which enable exploration and experimentation within an innovation system. At this point, it is worth mentioning that the priorities which are being set now will not be so forever and will include everything. In order to handle this unpredictable future, there should be a predicted mechanism for the revision of priorities. Smart specialisation should not eliminate any sectors explicitly (Foray and Goenaga 2013).

\section{Foresight as Stakeholder Involvement Policy Tool}

In order to avoid top-down failure on smart specialisation domains, it is important to look for methods which help policymakers define them (Foray and Goenaga 2013). To that end, the strategic intelligence tools for priority setting such as technology assessment, technology foresight or road-mapping are helpful (Georghiou and Harper 2011). The growing emphasis on different forms of strategic policy intelligence, such as foresight, reflects a substantial shift from top-down approaches of policy to network steering (Martin 2010a). Particularly, foresight activities emphasise widespread participation (large-scale processes involving thousands of scientists, industrialists, government officials and others) (Martin 2010b). Foresight deploys the processes of communication, coordination, participation and consensus-building to "create tomorrow" through taking immediate action today (Rogut and Piasecki 2011). This exercise mobilises private and public organisations, and industrial and service actors by developing new alliances between the producers and consumers of knowledge (Meissner 2012). Foresight is also seen as a driver of social learning processes, shared understandings and the formal and informal networks of experts from different fields (Habegger 2010).

The role exercised by foresight varies considerably between countries. In some, it is argued that the impact generated by the results of strategic policy intelligence exercises seems to be pretty low at national level but highly effective at the level of individual organisations (Gassler et al. 2004). Techniques such as technology foresight or technology assessment were very important in many countries in the 1980s and 1990s (i.e. the Netherlands), but since then, they have become less important and the role of bottom-up defined activities is much more stressed (Gassler et al. 2008). It is noted that available foresight methodologies are developed and applied mainly in industrialised countries and so may not be fully appropriate for the context of emerging economies (due to factors such as transitional social, economic and technological conditions) and may not be workable (Chan and Daim 2012). The negative image of the foresight is also linked with the bad experience of countries which have, half-heartedly or rarely professionally, carried out these studies with the result that they could not achieve the required results (Meissner 2012). 
The role of foresight has changed in recent years, and so, the stand-alone type of foresight activity aimed at developing research priorities has been questioned. According to the generational model of foresight,

- The first generation of foresights was characterised by technological forecasting which was carried out by experts and diffused to non-experts.

- The second generation involved industry and the market as the main actors.

- The third generation added a social and user-oriented perspective.

- The fourth generation moved from the national programme model towards a distributed role in the science and innovation system (Georghiou and Keenan 2006).

There is growing effort to bring research and innovation policy and strategy together and to use foresight for more joined-up policies and defining the appropriate policymix, especially demand-side measures such as public procurement, standards, regulation, clusters and platforms seeking to bring together demand and supply (Georghiou and Harper 2011). For example, the use of foresight based on the wide participation of regional stakeholders allows policymakers to enhance participation, commitment and the consensus of a community of citizens and firms to public procurement for innovation (Vecchiato and Roveda 2014).

The Governance Structure for Priority Setting and Stakeholder Involvement

Traditionally, the leading role in these processes is played by ministries, intraministerial bodies, intermediary agencies as sponsors of research, and researchers and research-performing institutions. In this context, the challenges related to the process of priority setting include issues such as who should be involved and how far to democratise this process, i.e. how to balance between technocratic and democratic approaches (Cervantes and Keenan 2010).

The priorities could be set at the strategic level (in decision-making procedures by ministries accompanied by advisory boards) and at operative level (by agencies that are organised more like private firms than government bodies). In many countries, there is a tendency to outsource policy measures or programmes from ministries to agencies (the process called as "agencyfication"). This decentralisation of governance structures increases the complexity and sets up a multi-layered structure (Gassler et al. 2008). There is no single model regarding the appropriate degree of centralisation or decentralisation of priority setting processes from this perspective. In some countries, the central government or central advisory body makes recommendations on priority areas for research and development (Austria, Japan, Norway, The Netherlands, Denmark, Germany, Korea), but in other countries, priority setting is left to individual ministries or agencies (Sweden) (Cervantes and Keenan 2010).

Governance structure can also be divided into three levels: policy (government), strategic (research-funding agencies) and operational (research-performing organisations). This mechanism of priority setting is based on the top-down approach if it is highly centralised and organised in a top-down way, i.e. the process of formulating priorities is a one-way direction from the top level down to the researchers. In this case, priorities usually reflect the governmental priorities expressed in official documents 
prepared by ministries which are often supported by advisory bodies (in some countries, such bodies have more power in this field) and consulted on with some stakeholders. In opposition to that, the bottom-up approach reflects the priorities of research organisations, researchers, entrepreneurs or citizens (Gassler et al. 2004). In that case, priorities are defined and implemented at the level of research-performing organisations. The bottom-up approach usually includes research-performing organisations, especially universities, receiving statutory funding (block grants), enjoying a high degree of autonomy and setting their own research priorities. The bottom-up approach concerns also the funding of fundamental research on a competitive basis. In that case, research topics are specified by applicants.

The role of policymakers is to allow and help entrepreneurial agents to discover what to do in the decentralised and bottom-up process (Foray et al. 2011). Policymakers should ensure that all stakeholders own and share the strategy, so governance schemes should allow for "collaborative leadership". This means that hierarchies in decisionmaking should be flexible enough in order to allow each actor to have a role and eventually take a lead in specific phases of the smart specialisation strategy design. The role is assigned according to characteristics, background and capacities (Foray et al. 2012). Some authors argue that the role of governments can go beyond that of a mere facilitator or catalyst and the pure entrepreneurial discovery process seems to be rather an exception than a rule.

Greater involvement of economic actors is more likely, particularly in more advanced regions than in less advanced areas which lack the necessary conditions to develop appropriate specialisation discovery processes by entrepreneurs. It is stressed that in some regions characterised by poor entrepreneurial capability, the main issue is a lack of entrepreneurial knowledge which can be strengthened through the mobilisation of extraregional resources such as the diaspora (Foray and Rainoldi 2013). As a consequence, it appears that the smart specialisation strategy requires the more active involvement of public authorities in less advanced regions. Regardless of the level of government involvement, the process must be as participatory as possible (Arancegui et al. 2011).

\section{Analytical Settings for Examination}

The theoretical context of this paper shows the need for an appropriate governance structure to ensure a wide range of possible actors in priority setting exercises and implementation mechanisms. The role of stakeholders is critical when it comes to the sensitive moment of deciding on strategic priorities. Then, a truly inclusive governance structure should be able to prevent its capture by specific interest groups, powerful lobbies or major regional stakeholders (Foray et al. 2012). Nevertheless, from the perspective of the whole process of priority setting, it is valuable to analyse stakeholder engagement in actions preceding such moments and afterwards, as well as their context.

Following the theoretical context, the main criteria of the examination to what extent do the chosen Polish initiatives facilitate the entrepreneurial discovery process for smart specialisation were structured in the following way:

- Governance structure and mechanism for priority setting

- Main actors and their motivations in the priority setting 
- Diagnosis and analytical background, priority selection (i.e. methods, tools)

- Results of priority setting activities (i.e. granularity of priorities)

- Implementation mechanisms (i.e. instruments)

- Monitoring and evaluation mechanisms

This structure presents similarities to the six steps presented in "Guide to research and innovation strategies for smart specialisation (RIS3)" (Foray et al. 2012).

The assessment of this criteria is made within the following scale:

- Poor, which means that the initiative does not tackle the issue of the criterion

- Relatively poor, where the initiative attempts to tackle the issue of the criterion

- Enough, meaning that the initiative somehow tackles the issue of the criterion

- Relatively good, which means the initiative has tackled the issue, but not fully

- Good, where the initiative tackled the issue in the proper way

The assessment was used to initiatives which were carried out in Poland over the last number of years and which are still in progress. By initiatives, this paper means different types of actions conducted by public authorities at national level and which represent some critical mass in terms of the scale and resources engaged by them (i.e. mainly financial and human resources). The activities which are not linked to the processes of priority setting for research and development (i.e. horizontal initiatives or those dedicated to support individual projects) were eliminated. To make the selection, we used the list of instruments of science and innovation policy prepared and actualised by the Ministry of Science and Higher Education. The list covers 149 instruments (version from April 2014). Historical data through studies, reports and evaluations published by public authorities were also collected. To complete and verify the data and information, some interviews were held with key stakeholders from ministries, agencies, NGOs, business and academia. Finally, from the very broad list of initiatives and activities, we selected 19 initiatives and activities which could be linked to the priority setting process or could support these processes (presented in Appendix). Some were linked to groups:

- INNOLOT programme and INNOMED programme as sectoral research programmes

- Advanced Technologies for Energy Generation, the Interdisciplinary System for Interactive Scientific and Scientific Technical Information, STRATEGMED and BIOSTRETEG programmes as strategic research and development programmes

The others were eliminated (e.g. initiatives dedicated to creating and maintaining databases). The final list of initiatives for further analysis is as follows:

- Foresight programmes

- Strategic research and development programmes

- Sectoral research programmes

The studies of initiatives will be preceded in the synthetic description of the historical context and the evolution of research in Poland. It is crucial to analyse and understand the involvement of stakeholders in priority setting in Poland. 


\section{Historical Context for Entrepreneurial Discovery Process in Poland}

Before WWII, the system of research and higher education in Poland was based on a similar pattern to that of Western systems with Humboldtian liberal university system. In the mid-1950s, it was reorganised on the centralised communist model with three groups of research-performing sectors: the higher education sector, the institutes of the Polish Academy of Science and industrial institutes (Jabłecka 2009). The research system under the communist economy was highly centralised with the dominant role played by a special ministry or committee for science and technology. The so-called "democratic centralism" allowed for feedback from bottom to top, but research institutions and other actors had very limited leeway in decision-making (Meske 1998). Since 1960, the governmental body responsible for science has been the Committee for Science. In 1972, the Committee was replaced by the Ministry of Science, Higher Education and Technology which in 1984 was replaced by the Committee for Science and Technological Development. The Presidium of the Committee for Science and Technological Development was composed of prominent government officials and governmentnominated representatives from science institutions. The Committee's decisions were implemented by the Office for Technological Development and Implementation. The Committee was responsible for preparing large centrally planned research programmes and the allocation of funds (under the strong influence of the communist party).

Between 1986 and 1990, the system covered 126 Central Programmes for Basic Research, 115 Central Research and Development Programmes, 200 Branch Research Programmes and 443 government-commissioned programmes. The programmes strengthened the sectoral division of the research system. This system bestowed upon the research community a certain degree of freedom due to the limited efficiency of centralised control (Jabłecka 2009). Although the research system was oriented towards the needs of industry, its research activities were not carried out in industry but rather for industry by industrial institutes (as opposed to business research and development). The enterprises (or, rather, production units) played a limited role as a source of technology and were treated as passive recipients of "R\&D achievements ready for implementation" previously developed by industrial institutes. Additionally, the research system was characterised by extensive imitative and "re-inventing the wheel" type of technological efforts (Radosevic 1996).

It is important to stress that under the communist system, the role of private entrepreneurs was highly limited. In Poland in 1988, the last communist government passed an act (called Wilczek's law) which constituted that undertaking and performing business activity was free. It allowed everyone and enterprises, in their framework of activity, to undertake all entrepreneurial steps not prohibited by law. This regulation unlocked entrepreneurship potential in Poland and helped to recreate the entrepreneurial culture. As a result, more than half a million new enterprises were registered in 1989 , with the number rising to nearly 2 million at the end of 1992 (99\% of them were microenterprises with less than 10 employees) (Kowalewski and Rybiński 2011).

Since the collapse of the communist system, Poland has undergone significant changes related to the market-based economy and its accession to the European Union. In 1991, the research funding system in Poland was also reformed. The central role in this system was played by the Committee for Scientific Research which had ministerial status and decisive competences in the field of research. The Committee was managed 
by researchers and consisted of five members nominated by the government and 12 elected by the research community. The role of politicians was reduced from the entire decision-making process (Jabłecka 2009).

The Committee carried out science policy without setting priorities for research and development. It was argued that there was a weak rationale for priority setting due to the low budget allocation for science. The selection of priorities might either eliminate many ambitious research projects which were not in line with such priorities or ensure funding for research institutions which were in line with these priorities and had "political" power but did not represent high-quality research (Kozłowski 2012). So, the system of research funding was based on a disciplinary, bottom-up approach and upon scientific priorities with a lack of clear and specific research priorities relevant to social and economic needs (Jabłecka 2009). As a result, public research funding was dominated by a large number of low-scale, mainly scientifically oriented projects. The management of this research system was dominated by representatives of the research community, and the role of different groups of stakeholders, especially entrepreneurs, was very limited. It was reflected in research and development statistics which showed a very low share of business research and development expenditures. The public research budget was dedicated mainly to research organisations.

In 1992, the Committee introduced a scheme dedicated to supporting thematic projects (so-called ordered projects) which were solicited by the ministries, institutions or regional administration. Researchers were selected on a competitive basis. The share of public funding dedicated to this scheme in the total budget for research in 1992-1996 increased from 0.2 to $2.6 \%$. In 1997, after the control of the Supreme Audit Office (NIK) and its critique about the low effectiveness of this scheme, the activity was modified. Two subschemes of ordered projects were established: goal-oriented projects and those ordered by the Committee. Despite this modification, the scheme was still criticised due to the low applicability of project results (only $25 \%$ of the projects were effective and their results were practically used). One reason was that public institutions, which solicited project topics, did not take the risk of inaccurate topics and the potential lack of implementation of project results (NIK 2002).

Since the turn of the century, the research funding system has been criticised. The government lacked the capabilities to set long-term priorities. Public research funding was dispersed around small projects with very little competitive funding for larger and priority-linked projects to meet strategic goals (OECD 2007). Additionally, the cooperation between enterprises and research organisation was weak, and the level of R\&D spending was very low compared to other countries (Goldberg 2004). To overcome these weaknesses, in 2004, the Act on the Principles of Financing Science came into force. This law established the new system and rules for research funding in Poland. The Committee for Research has been replaced by the ministerial model with the Minister of Science who has the decision-making role in the field of research policy and funding. The Minister of Science is advised by the Research Council which constitutes the formal representation of the research community. Opponents (mainly recruited from the academic community) labelled these changes as a "transition from the democratic model to the 
ministerial model" (Jabłecka 2009). These modifications were accompanied by the growing need to create a public debate on the language and culture of thinking about the future, as well as to rationalise public expenditure on research and development and focus on areas that are important for future economic development.

\section{The Polish Foresight Programmes}

Delayed, compared to Western countries, the idea of foresight became very popular in research and policymaking circles in Poland at the beginning of the 2000s (OkonHorodyńska 2007). Following the criterion of the project's initiator, two groups of foresight projects could be identified in Poland: national and sectoral/regional foresight projects.

\section{National Foresights}

The national foresight projects were initiated by the national government. These projects could be called top-down initiatives. In such cases, stakeholders play an important role in motivating the government, but the decision to begin the projects and their scope-setting was undertaken by the government. The first national foresight programme started as a pilot project in 2004 and was dedicated to health and life issues. Thereafter, two more foresight projects were carried out: the National Foresight Programme-Poland 2020 (2006-2009) and Project Insight 2030 (2010-2011). The National Foresight Programme-Poland 2020 (the NPFPoland 2020) was launched by the Ministry of Science and Higher Education. The structure of the NPF-Poland 2020 consisted of the Main Panel and three research field panels (sustainable development, ICT and safety) and the support group. The Steering Committee had also been established to ensure better cooperation between the consortium and the Ministry. The Main Panel and Steering Committee were dominated by representatives of the research sector and government organisations (only one person represented the industrial cluster). There were various methods used in the NPF-Poland 2020 like Delphi, SWOT, scenario development and cross-impact analyses, and expert panels. The first round of Delphi analysis included 2833 respondents (from 9281 to whom the questionnaire was sent), and in the second round, 2554 respondents participated. Participant distribution is presented in Fig. 1 (Okoń-Horodyńska 2009).

The participation data shows that non-research participants were in the minority.

The Project Insight 2030 was launched by the Ministry of Economy and realised by the Polish Chamber of Commerce for High Technology (the Institute of Fundamental Technological Research was a member of the consortium). The structure of the project consisted of the Steering Committee, Main Panel and 10 research area panels around industrial biotechnologies, nanotechnologies, advanced manufacturing systems, IT technologies, microelectronics, photonics, development of clean coal technologies, rationalisation of energy utilisation, modern equipment for the manufacturing industry and technological innovation in natural resource acquisition. The main methods used in the Project Insight 2030 were Delphi, SWOT, brainstorming and cross-impact analyses. 


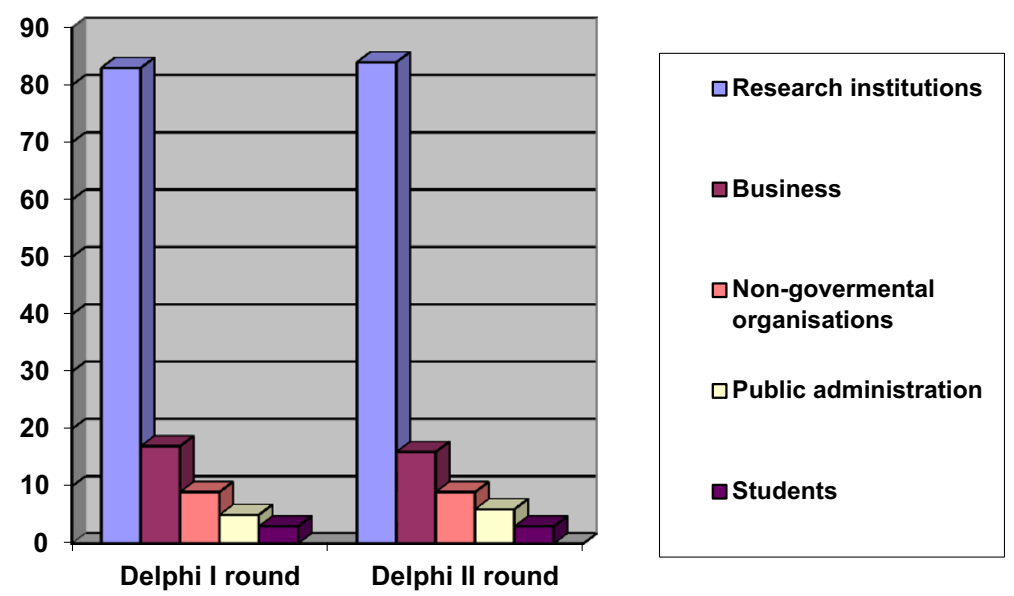

Fig. 1 The distribution of Delphi participation in NPF-Polska 2020 (\%). Source: Own elaboration

It is interesting that this foresight was mainly addressed to the industrial sector, but the share of respondents of Delphi analysis represented mainly the research sector (see Fig. 2) (Czaplicka-Kolarz et al. 2011). Under the project, 99 technologies were identified in 10 research domains which reflect the specialisation of the research area panels.

Both provided cases show the weak participation of business representatives, so the results can be considered as research-oriented and not market-oriented.

Sectoral and Regional Foresights

The second group of foresight activities in Poland could be characterised as bottom-up initiatives. They were financed mainly from EU structural funds: 18 projects were financed from the Sectoral Operational Programme Increasing Competitiveness and Innovativeness from 2004 to 2006 (total budget 34 million PLN), with 24 financed from the Operational Programme Innovative Economy from 2007 to 2013 (total budget -46

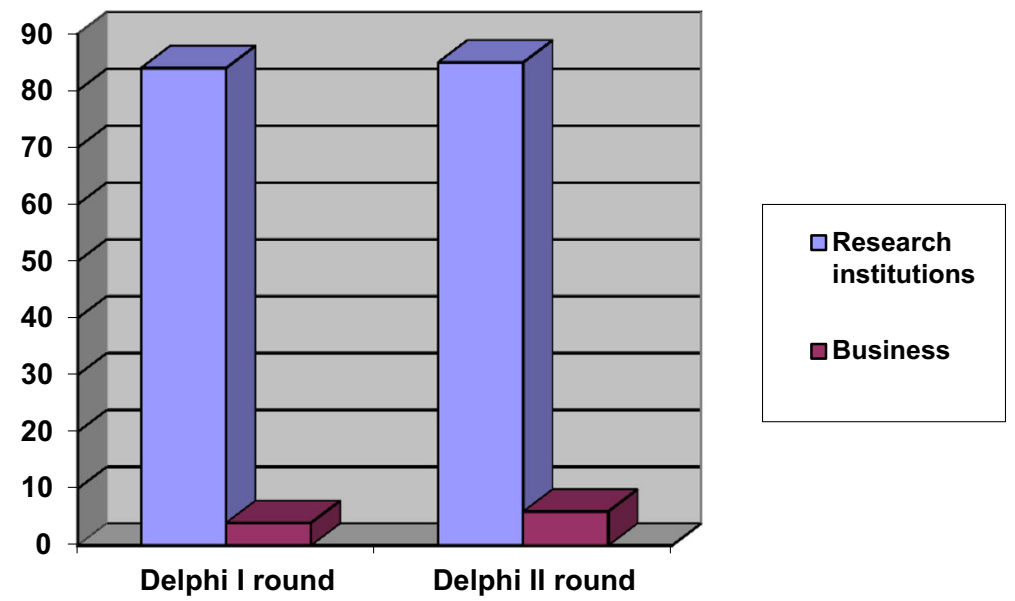

Fig. 2 The distribution of the Delphi participation in Project Insight 2030 (\%). Source: Own elaboration 
million PLN). The projects generally take into account sectoral perspective and concern industries dealing with energy, waste management, agriculture, the food industry and several high-tech areas. Some projects link the sectoral perspective with new technologies ("Directions of material technology developments for the needs of aviation cluster Aviation Valley") or regional perspective ("Technological foresight "NT FOR Podlaskie 2020 ". Regional strategy of nanotechnology development"). Some were dedicated to more horizontal issues, such as the future of higher education, human resources in modern economy or quality of life and information society (i.e. "Technological foresight of public services development in Upper Silesia Metropolitan Area").

Despite the sectoral and industrial dimension of many foresight projects, business actors were a small minority among foresight partners. The exceptional case was the project coordinated by the cluster Aviation Valley. This project managed to engage 61 partners, including 59 enterprises and two research organisations. The leading role of business in this project was also reflected in its title which emphasised the need for the development of material technology for the needs of the aviation industry. Two other sectoral foresight projects, which can be distinguished from the rest projects in terms of the engagement of business partners, were dedicated to lignite extraction and the processing industry (six research organisations and seven enterprises) and satellite and cosmic technologies (12 research organisations and 5 enterprises) (Nazarko et al. 2013). The aviation and lignite industries play an important role in the Polish economy, but satellite and cosmic industries could be examples of an emergent niche (possibly the example of radical foundation or diversification of the smart specialisation nomenclature).

The majority of these projects used the SWOT, scenario building, Delphi methods and expert panels. The organisational structure was very similar to the structure of national foresight programmes and included steering committees, main panels and research panels. The main groups of participants are representatives of research organisations, but in some projects, the share of business representatives exceeded $50 \%$ (as mentioned, the aviation valley project) (Nazarko et al. 2013). In most projects, the majority of Delphi survey participants were from research organisations. This made the survey results somewhat biased. In some projects, it was attempted to some extent to eliminate bias through the applications of weights attributed to the particular expertise level (Czaplicka-Kolarz et al. 2009).

\section{Evaluation of Foresight Exercises}

So far, three evaluation of foresight exercises have been carried out in Poland. Two of them referred to foresight activities but were among those of the Operational Programmes. One was commissioned by the Ministry of Science and Higher Education in 2010. This was directly tailored to the evaluation of foresight projects (Nazarko et al. 2011). The evaluations of the Operational Programmes show that the results of foresight projects were very useful for the research organisations carrying out these projects, but not especially for policymakers. The bottom-up approach in selecting sectoral and regional foresight initiatives resulted in the dispersion of the areas covered and the lack of synergy and cohesion between results (Pbid Re-source and FUM 2009; Kościelecki et al. 2011).

The outcomes of the foresight projects were reports presenting scenarios, roadmaps and recommendations to business and research organisations, forms of communications with policymakers and stakeholders. Results are usually presented on project websites. 
The national foresight projects, as well as regional and sectoral projects, have brought much valuable experience. First of all, they have initiated the debate about the future development of the country, regions, sectors or more horizontal issues which are important for socio-economic development. The positive effect of these foresight activities is also the establishment of foresight community, especially from the research and academic cohort. These communities bring together many experts who still cooperate despite the fact that most of the projects finished several years ago. The community plays an important role in developing foresight ideas and methods. The main weakness of these foresight projects was the minimal participation of business representatives (approximately $80 \%$ of Delphi survey participants came from academic and research organisations). The other weakness is the implementation of foresight project results. It is worth noting that from 21 sectoral foresight projects, there exist only four institutions responsible for the implementation of results (Nazarko et al. 2013). Quite often, the reports present general recommendations which usually confirm well-known assumptions and do not suggest how to put the results into reality and link them to research and innovation funding. The observation of Polish foresight activities shows also that one of the main challenges is to achieve and maintain continuous contact with business society in addition to ensuring the declaration of cooperation to real financial contribution -it is much easier to present proposals during discussions and consultations but much more difficult to make decisions which result in financial obligations.

\section{Follow-up}

To address the above-mentioned weaknesses, two instruments have been introduced. The first is a programme entitled "the National Foresight Programme -implementation of the results" which was initiated by the Ministry of Science and Higher Education in 2011. Its main goal is to develop and implement methods and tools to analyse national and regional research and innovation potentials, the results of foresight studies and similar projects. Additionally, the aim was to support national and regional policymakers in making decisions about research and innovation issues, in particular setting priorities for research and innovation.

The second instrument is the KREOBOX Platform, which is a virtual meeting place for researchers, investors and entrepreneurs where they can submit ideas and find money for their implementation. The platform provides access to a database of experts, research equipment and ready-made technologies. It also supports employers, employees and students to better link their needs and expectations in terms of job market requirements.

\section{Strategic Research and Development Programmes}

\section{Strategic Vision and Priority Setting}

According to the assessments of the Act on the Principles of Financing Science from 2004, the main weaknesses of the Polish research system were the fragmentation of research and the lack of large research projects oriented to socio-economic needs. To 
tackle these findings, the above-mentioned Act introduced new policy mechanisms which consisted of two phases:

1. The preparation of strategic documents

2. A funding scheme based on the rules and research priorities indicated in this document

The strategic document was named "The National Framework Programme" (the NFP). The NFP was based on the conviction that research can be neither subjected solely to free market rules nor be left in the hands of scientists alone. The decisionmaking process should involve government as policy maker, researchers and entrepreneurs. This was an evident turnaround to the former governance and research funding system. According to this Act, the NFP should be prepared by the Minister of Science on the basis of proposals submitted by research organisations, universities, the Polish Academy of Science and regional authorities (voivodes, marshal of the voivodeship). The right to submit proposals also belonged to nationwide representations of business and industry. Finally, over 1600 proposals were submitted with various levels of detail. On this basis, the Ministry of Science and the Council for Science prepared a draft of the NFP. The final version of the NFP was accepted by the Minister of Science in 2005. The NFP indicated nine strategic research areas (health, environment, agriculture and food, state and society, security, new materials and technologies, information technologies, energy and its resources, transportation infrastructure) and 38 priority directions for scientific research (e.g. in the area of new materials and technologies: nanomaterials and multi-function nano-assemblies, advanced materials and electronic and optoelectronic equipment, advanced construction materials, industrial product technologies and biotechnologies) (MES 2005).

The instrument used to realise the priority directions of scientific research under the NFP was the ordered projects. Calls for ordered projects were based on a two-stage procedure. The first stage was a submission of proposals for ordered projects with a three to four-page justification, estimated costs and anticipated results. These judging teams were appointed by the Minister of Science and were responsible for preparing call frameworks including proposal topics and terms. The institutions performing the ordered projects were selected on a competitive basis (MES 2005). The Ministry of Science and Education was responsible for the preparation of the NFP as well as the funding of ordered projects (both strategic and operative levels). It established 478 ordered projects from 1991 to 2008, including 53 (22 in the field of agriculture and natural science) with a total budget about 440 million PLN over the last 4 years. The share of funding dedicated to ordered projects in these years did not exceed $4 \%$ of the total public budget for science.

This mechanism was modified in mid-2007 when the National Centre for Research and Development (as a governmental agency subordinate to the Minister of Science) was established to focus on managing and funding, on a competitive basis, large-scale strategic research and development programmes. In October 2008, the NFP was replaced by "The National Research and Development Programme" (The NRDP). The NRDP was adopted by the Minister of Science. This document was prepared by the Research and Science and Technology Committee of the Council for Science, the Interdisciplinary Team for Strategic Research and Development Programmes and 
experts from the Ministry of Science and Higher Education (formerly the Ministry of Education and Science). The draft NRDP was formed through consultation with scientists, business, and public administration representatives (both national and regional level) (MSHE 2008).

The NRDP indicated five prioritised areas of research (society under safe and sustainable development, health, energy and infrastructure, modern technologies for the economy, agriculture and forestry) and 30 directions of research. They were further divided into a large number of more detailed research topics. Additionally, the NRDP appointed 10 strategic research and development programmes including descriptions of their goals, rationales, scopes and expected effects. By the end of 2008, two strategic research and development programmes had begun: the Advanced Technologies for Energy Generation (2010-2013, budget 59.8 million PLN) and the Interdisciplinary System for Interactive Scientific and Scientific Technical Information (2010-2015, budget 275 million PLN). The management of these programmes was commissioned to the NCRD which identified specific research topics (with the support of an interdisciplinary group of experts) and selected researchers on a competitive basis (using a peer-review procedure).

The experience with the NFP and NPRD revealed the problems associated with the transparency of priority setting and implementation processes. Critics of this priority setting exercise argue that such priorities could eliminate access to public money for projects which are valuable to the economy and society but are not in line with selected priorities. Having narrowly defined priorities and implementation instruments (as in the NRDP) lead to a situation where at operative level, there is no room to make adjustments to include actual market needs and opportunities. Decisions relating to the selection of specific priorities and research topics were to some extent subjective and made mainly by representatives of the research community. On the other hand, the use of a broad definition of priorities (as in the NFP) results in the possibility that each project could be funded because it might be easily assigned to one of the stated priorities. Finally, the process of priority setting in the NFP does not bring about expected results regarding the concentration of public resources on selected priorities. Moreover, the processes of the identification (strategic level) and clarification of priorities (operative level) were not transparent and were dominated by researchers. The implemented approach could have been more vulnerable to some lobbying groups which prefer to dominate areas of research rather than emerging market topics.

In 2010, two new Acts -on the Principles of Financing Science and on the NCRD came into force. According to these changes, the NCRD has been empowered, especially in the field of supporting business research and development. Additionally, the NRDP was replaced by the National Research Programme (NRP), and the mechanism of strategic research and development programmes has been modified. The NRP was prepared by the Committee for Science Policy and the Ministry of Science and Higher Education. The interministerial and public consultations attracted the attention of organisations representing industry and research organisations. In the NRP, the results of the NPF Poland 2020 were taken into account. The NRP was accepted by the Council of Ministers (the NFP and NPRD were accepted by the Minister of Science). The NRP specified seven strategic priorities for research and experimental developments (MSHE 2011): 
- New energy technologies

- Lifestyle diseases, innovative drugs and regenerative medicine

- Advanced information and telecommunication technologies and mechatronics

- Advanced materials

- Natural environment, agriculture and forestry

- Social and economic development of Poland in the globalised markets

- National security and defence

These strategic priorities are general and rather refer to comprehensive research fields and cannot be regarded as a genuine source of the prioritisation of research investments. The priorities offer guidance for the Council of the National Centre for Research Development to define drafts of the strategic research and development programmes (Klincewicz 2014). The drafts are prepared by the Commission for the Strategic Research and Development Programmes (one of the four commissions set up by the Council of the NCRD) and then presented to the Council of the NCRD and the Minister of Science for approval. The Council includes economic, scientific and public administration representatives (10 representatives from each group). It acts as an independent body which focuses and deals with the different views and interests reflecting the aspirations of various groups. The Council of the NCRD defines strategic research and development programmes as well as the order in which these are prepared.

The creation of the strategic research and development programme is a multistep process based on the consultation and agreements among stakeholders which are gathered around the particular research topic. Additionally, this process is supported by external analysis and expertise, the aim of which is the identification of topics which could fully meet societal challenges and are based on research and economic capacity. The programme consists of a definition of thematic scope, objectives to achieve this (both main and sub-objectives), a budget, and a monitoring and evaluation system. The thematic scope includes an indication of sub-thematic groups and/or specific research topics.

The programme is based on the top-down approach which means that applicants should meet thematic requirements as defined in the programme. As a rule, the application should be provided by the research consortia which gather scientific and business or social partners. The goal of this approach is to stimulate cooperation between research teams, integrating them around the key issues important for national development. Applications are assessed by five reviewers, but the final score is an average of three after the rejection of two opposite extreme ones. The review criteria include scientific value with the assessment of the innovativeness of the expected solution, experience of applicants, predicted societal and economic outcomes, own financial contribution and cost-efficiency. Currently, the NCRD is implementing two strategic research and development programmes based on the NRP: STRATEGMED and BIOSTRATEG.

The programme STRATEGMED (Prevention practices and treatment of civilisation diseases) refers to the NRP's priority lifestyle diseases, innovative drugs and regenerative medicine. The programme is a response to the needs of an aging society, an observed increase for chronic diseases and increasing costs of healthcare. Its objective 
is to have a progress in civilisation disease treatment and regenerative medicine. The programme covers the four thematic groups which include more precise topics:

- Cardiology and cardiac surgery (e.g. research on sensitive biomarkers, research into methods of treatments, the treatment of essential hypertension)

- Oncology (e.g. research on molecular detection of cancer for personalising therapy)

- Neurology and senses (e.g. development of biomarkers of cognitive and sensory deficits, biomarker individual response to pharmacological treatment of diseases)

- Regenerative medicine (e.g. studies on stem cell surface markers)

It is expected that the programme should stimulate innovativeness and competitiveness of the Polish economy in areas of biotechnology and biomedical engineering by technology transfer to enterprises. The additional expectation is the creation of many dynamic and young research teams. The budget for the period $2012-2017$ is 800 million PLN.

The programme BIOSTRATEG (Natural environment, agriculture and forestry) refers to the NRP's priority: natural environment, agriculture and forestry. The goal of the programme is the development of knowledge in the areas covered by the programme, upgrading the international position of Polish science and the transfer of innovative solutions developed within the programme into the social and economic environment. The programme should also stimulate the private sector in research activities in the fields of the natural environment, agriculture and forestry.

The programme covers five strategic areas of research:

- Food security and food safety

- Rational management of natural resources, with particular emphasis on water management

- Counteraction and adaptation to climate change, with particular emphasis on agriculture.

- biodiversity conservation and sustainable development of the agriculture production area

- Forestry and wood industry

The budget for the period 2014-2019 is 500 million PLN of (at least $10 \%$ of the total budget of the programme from private contribution). In October 2013, the Council of the NCRD took the decision to prepare a new strategic research and development programme in the field of advance materials (modern material technologies). The programme draft was prepared by the NCRD with external experts and discussed by the Council of the NCRD in June 2014.

\section{Sectoral Research Programmes}

As mentioned in the previous section, in 2010, the new Act on the NCRD came into force which empowered the NCRD, especially in the field of supporting research and development carried out by enterprises. One of the new instruments which has been introduced on that basis by the NCRD is the support for so-called sectoral research 
programmes. These have been established as a response to the needs identified by industry and other stakeholders in specific research areas. The goal of sectoral research programmes is to prepare research and development agendas which are negotiated between public and private partners and then financed by the NCRD. Research projects are funded on a competitive basis and should be in line with the research agendas negotiated by private and public sector representatives. In sectoral research programmes, the public sector is represented by the NCRD, while the private sector is represented by nominees from industry or other stakeholder groups (i.e. technology platforms, clusters, chambers of commerce). These organisations play a leading role in the identification of research priorities and the preparation of research and development agendas.

The procedure of preparing and establishing programmes includes the submission of a draft proposal prepared by stakeholder representatives which should be formally organised (legal entity) and represent a group of enterprises, NGOs and other partners expressing readiness to create research agendas. The application should include analysis of competitiveness and innovation in industry from the national and international perspective, the draft research agenda including research problems, the availability of research infrastructure and expected results, in particular the impact of the proposed agenda on the competitiveness and innovation of companies. The application is evaluated by the NCRD, particularly in terms of intervention goals, estimated budgets and expected outcomes.

Under this procedure, in 2012-2013, two sectoral programmes were introduced: INNOLOT programme and INNOMED programme. The goal of the INNOLOT programme is to support research and development, the results of which could be used by aviation companies to increase their competitiveness and innovativeness (NCRD 2013a). The programme was initiated by the Polish Aeronautical Technology Platform which groups companies associated in clusters: Aviation Valley with its headquarters in Rzeszów (Podkarpackie region), Greater Poland Aviation Valley with a location in Kalisz (Great Poland region) and the Federation of Aviation Companies with its location in Bielsko (Ślasskie region). The general agreement on the establishment of the programme was signed by the industrial partners and the NCRD on 19 January 2012. According to the agreement, the strategy with the identification of priorities should have been prepared by 28 May 2012 but was finally prepared and enclosed to the agreement on 8 November 2012. In May 2013, the first call for applications was announced. The total budget of the programme, which will be realised from 2013 to 2018, is about 500 million PLN, of which 200 million PLN comes from business. Beneficiaries of the programme are to be the research consortia of companies and research organisations (with leading role of companies). The research and development priorities in the research agenda of the INNOLOT programme have been defined by stakeholders, in particular by companies from the Polish aviation industry. Due to the strong engagement of companies, the priorities of the INNOLOT programme have been defined in a very specific and technical way. The INNOLOT programme identifies three main technology demonstrators and 22 technology demonstrators. The three main technology demonstrators are the following:

- Innovative engine

- Innovative helicopter

- Innovative aircraft 
Each technology demonstrator is charged with specific research tasks which have been based on analysis of their research and the industrial potential with research and economic indicators. Research tasks are carried out by research teams (with the leading role taken by teams from companies) which are selected on a competitive basis by the NCRD. The selection of projects and teams is carried out in two stages which should ensure that funding will be available only to the best projects that are in line with the scope of technology demonstrators and research tasks. The project is coordinated by the Steering Committee which consists of seven members: four business representatives, one representative of the NCRD and two representatives from technical universities. The key document, which constitutes the background to the agreement with the NCRD, is entitled "Research Strategy for Aviation Industry 2012-2035". This document was prepared from the inspiration of the Polish Aeronautical Technology Platform. It is the result of the 3 -year work carried out by experts from the business and research sectors (PPTL 2014). It is interesting that the above-mentioned document does not indicate the foresight programme carried out a few years earlier as the reference document. This foresight project, as others realised in Poland, has mainly intangible effects such as creating a communication platform or cooperation networks. It confirms that the impact of foresight project results was effective at the organisational level but not necessarily on policymaking at sectoral or national levels.

The goal of the INNOMED programme is to support research and development related to innovative medicine. The programme was initiated by the Polish Innovation Medicine Technology Platform. The budget of the programme is about 300 million PLN. The programme is dedicated to companies and research consortia which are engaged in developing new drugs. The process of preparing a research agenda in that case was longer than the case of the INNOLOT programme. The work on the programme was initiated in 2011, and in July 2012, the first meeting with the companies took place. The first call for applications was published in May 2013. The research funding under the programme is based on competitions dedicated to specific research areas identified by the Steering Committee and stakeholders. The Steering Committee consists of seven members representing business, research institutes, hospitals and the NCRD. The first competition was dedicated to innovative products and technologies in oncology. One of the main formal conditions of this programme is that the results of research and development should be commercialised no longer than 5 years after the conclusion of the research projects (NCRD 2013b).

In 2014, the procedure relating to the preparation of research agendas has been simplified. The first step is the submission of a feasibility study which is in fact the application of setting the sectoral research programme. The study should be prepared by the business representatives and other stakeholders and should include a diagnosis of the current situation in the selected sector, an analysis of competitiveness and innovation in industry from national and international perspectives, SWOT and PEST analyses, a draft research agenda with identified research problems, goals and an estimated budget. The feasibility study is evaluated by the NCRD. Business partners interested in preparing the feasibility study could receive a grant to reimburse $50 \%$ of total costs of the study but no more than 30,000 euro. 


\section{Discussion and Conclusions}

The role of the involvement of stakeholders to priority setting for research and development has changed over the last 30 years in Poland. These changes were possible due to the economic and social transformation and the evolution of the research system. Under the communism, the research system was highly centralised, and stakeholders did not participate in the decision-making processes. Additionally, in general, the activities of private entrepreneurs were very limited by law. At the beginning of the transformation, the research funding system was still centralised, but the role of representatives from the research community increased substantially. Nevertheless, the engagement of entrepreneurs in the research system was very low.

Since 2004, the research funding system has evolved again and followed in line with trends observed in Western countries (specifically a trend called agencyfication and the establishment of the NCRD). The research system has been more decentralised and opened to stakeholders like entrepreneurs and NGOs. The role of the stakeholders differs in various initiatives and activities such as the foresight programmes, strategic and research programmes, and sectoral programmes. The summation of our examination of the described initiatives is presented in Table 1.

\section{Foresight Projects}

The foresight projects carried out in Poland have had a positive impact on the engagement of the research community to set research and innovation priorities. Although the national foresight programmes represent the top-down approach, the consultations with stakeholders played a crucial role. The sectoral foresight programme, initiated mainly by a research organisation, represents the bottom-up approach. The weakness of the foresight projects is the minimal engagement of stakeholders, such as policymakers and entrepreneurs (with the exemption of a project carried out by cluster Aviation Valley). The lack of industrial and governmental partners in many foresight projects might indicate that the level of awareness of the potential benefits and the readiness to discuss future development are still very low. The foresight projects were dominated mainly by scientists, and Polish enterprises are rather sceptical of taking advantage of these exercises. Taking into account the generational model of foresight, the foresight exercises carried out in Poland could be generally classified as first- and second-generation projects. The main challenge for the future will be how to move these activities to third- and fourth-generation projects.

Due to the low engagement of actors other than representatives of the research community, foresight projects cannot also be treated as an entrepreneurial discovery process. Nevertheless, they could serve as an example of an analytical step to start and strengthen such processes or the development of collaboration networks, such as in the case of Polish Aviation Valley. The majority of foresight projects concentrate on supply rather than demand even when they take into account the wider context and link the science and technology setting to societal goals. It characterises the foresight projects also carried out in many other Central and Eastern Europe countries (Edler 2011). To be more useful for policymaking processes, it will be necessary to put more emphasis on the issue of how to better link foresight exercises 
Table 1 The summation of characteristics of the initiatives from the perspective of entrepreneurial discovery and stakeholder involvement in priority setting

\begin{tabular}{|c|c|c|c|}
\hline & The foresight programmes & $\begin{array}{l}\text { The research and } \\
\text { development programmes }\end{array}$ & $\begin{array}{l}\text { The sectoral research } \\
\text { programmes }\end{array}$ \\
\hline $\begin{array}{l}\text { The governance } \\
\text { structure and } \\
\text { mechanism of } \\
\text { priority setting }\end{array}$ & $\begin{array}{l}\text { National foresight projects } \\
\text { were initiated by the } \\
\text { ministries (top-down } \\
\text { approach). Sectoral and } \\
\text { regional foresight } \\
\text { programmes were } \\
\text { initiated by stakeholders, } \\
\text { mainly research } \\
\text { organisations (bottom-up } \\
\text { approach). There was no } \\
\text { coordination mechanism } \\
\text { of these initiatives, so } \\
\text { some domains (sectors, } \\
\text { regions) were covered by } \\
\text { more than one project. } \\
\text { The Steering Committee } \\
\text { members and } \\
\text { coordinators of these } \\
\text { programmes are mainly } \\
\text { representatives of the } \\
\text { research community or } \\
\text { administration. }\end{array}$ & $\begin{array}{l}\text { The programmes are } \\
\text { initiated by } \\
\text { governmental agencies } \\
\text { on the basis of the } \\
\text { strategic document (the } \\
\text { NRP) accepted by the } \\
\text { government (top-down } \\
\text { approach). } \\
\text { The Steering Committee } \\
\text { members and } \\
\text { coordinators of the } \\
\text { programmes are mainly } \\
\text { representatives of the } \\
\text { research community or } \\
\text { administration. }\end{array}$ & $\begin{array}{l}\text { The programmes are } \\
\text { initiated by the } \\
\text { entrepreneurs and } \\
\text { organisations } \\
\text { representing them } \\
\text { (bottom-up approach). } \\
\text { Steering Committee } \\
\text { members and } \\
\text { coordinators of the } \\
\text { programmes are } \\
\text { representatives of } \\
\text { business and to a lesser } \\
\text { extent the representatives } \\
\text { of the research } \\
\text { community and } \\
\text { administration. }\end{array}$ \\
\hline Assessment & Relatively Poor & Relatively Poor & Relatively Good \\
\hline $\begin{array}{c}\text { The main actors and } \\
\text { their motivations } \\
\text { in priority setting }\end{array}$ & $\begin{array}{l}\text { The foresight programmes } \\
\text { involved different } \\
\text { groups of actors, but } \\
\text { were dominated by } \\
\text { researchers. The } \\
\text { engagement of } \\
\text { entrepreneurs was } \\
\text { generally low (the } \\
\text { exception-a project } \\
\text { carried out by the Custer } \\
\text { Aviation Valley). } \\
\text { The main motivation for the } \\
\text { government was to } \\
\text { create public debate } \\
\text { about the future } \\
\text { development and set up } \\
\text { the priorities which will } \\
\text { have an impact on social } \\
\text { and economic growth. } \\
\text { For the researchers the } \\
\text { motivation was to get } \\
\text { access to knowledge } \\
\text { about future } \\
\text { development, establish } \\
\text { knowledge networks and } \\
\text { strengthen cooperation } \\
\text { with business. } \\
\text { The programmes were } \\
\text { mainly supply side- }\end{array}$ & $\begin{array}{l}\text { The strategic document (the } \\
\text { NRP) was prepared by } \\
\text { the Ministry of Science } \\
\text { and Higher Education } \\
\text { and consulted with the } \\
\text { business and research } \\
\text { communities. } \\
\text { The programmes are } \\
\text { prepared by NCRD } \\
\text { experts, consulted with } \\
\text { stakeholders - mainly } \\
\text { researchers, and } \\
\text { accepted by the NCRD } \\
\text { Council. } \\
\text { The main motivation for } \\
\text { government was to } \\
\text { concentrate public } \\
\text { resources on selected } \\
\text { priorities and strengthen } \\
\text { cooperation between } \\
\text { research organisations. } \\
\text { The motivation for } \\
\text { research } \\
\text { organisations - the } \\
\text { increase of public } \\
\text { funding on selected } \\
\text { priorities which are in } \\
\text { line with their } \\
\text { specialisation. }\end{array}$ & $\begin{array}{l}\text { Initiated by industrial } \\
\text { partners (i.e. technology } \\
\text { platforms or clusters) } \\
\text { and managed by } \\
\text { industrial partners and } \\
\text { governmental agencies. } \\
\text { The motivation for the } \\
\text { government is to } \\
\text { concentrate public } \\
\text { funding on the topics } \\
\text { deemed important from } \\
\text { the business perspective. } \\
\text { The motivation for } \\
\text { enterprises-the increase } \\
\text { of public funding on } \\
\text { domains important from } \\
\text { their perspective. } \\
\text { The programmes were } \\
\text { mainly demand side- } \\
\text { oriented (the perspective } \\
\text { of entrepreneurs). }\end{array}$ \\
\hline
\end{tabular}


Table 1 (continued)

The foresight programmes

oriented (the perspective of researchers).

Assessment
Diagnosis and
analytical
background to
priority setting,
priority selection
tools

\section{Assessment \\ Priority setting activities (granularity)}

\section{Relatively poor}

Prepared by experts from research organisations with different methods (i.e. Delphi, crosssectoral, brainstorming, roadmapping, SWOT/ PEST methods). Dominance in these analyses of representatives of the research sector with low engagement of industrial and governmental representatives.

\section{Enough}

Usually broadly defined general priorities (4-8) and a large number of more detailed priorities (sometimes more than 100). Some foresights do not indicate the priorities.
The research and development programmes
The sectoral research programmes
The programmes were mainly supply-side oriented (the perspective of researchers).

\section{Relatively poor}

Prepared by experts and representatives of the NCRD (expert group responsible for preparing strategic research and development programmes). The diagnosis include SWOT analysis, literature review and brainstorming. In some programmes the results of foresight projects were used (i.e. BIOSTRATEG). The experts represented mainly research organisations. The domains of the programmes were covered by the foresight programmes, but there are no direct references to these in the strategic research and development programmes. programmes: three to
Relatively good

Prepared by industrial experts and representatives of the NCRD. In some cases (i.e. Aviation Valley) the results of foresight activities were used. The diagnosis includes SWOT analysis, literature review and brainstorming. The aviation industry was the area of analysis by the foresight programme, but there is no direct reference to this in the sectoral research programme.

\section{Enough}

Broadly defined priority areas in the NRP (seven priorities) and in the strategic research and development four general priorities which are elaborated, usually in a large number of detailed research topics or technologies.

Enough

Priorities defined in terms of technology demonstrations (products at early stage of development) elaborated by the detailed technologies crucial to produce the demonstrators (INNOLOT). There are also broadly-defined priorities (INNOMED). The granularity depends of the specific sectoral context.

Relatively good

Relatively good

Dedicated public funding to support projects which are in line with identified
Public-private mechanisms based on competitive implementation mechanisms
Usually lacking the mechanism of implementation or very 
Table 1 (continued)

\begin{tabular}{|c|c|c|c|}
\hline & The foresight programmes & $\begin{array}{l}\text { The research and } \\
\text { development programmes }\end{array}$ & $\begin{array}{l}\text { The sectoral research } \\
\text { programmes }\end{array}$ \\
\hline & $\begin{array}{l}\text { general } \\
\text { recommendations } \\
\text { addressed to government } \\
\text { and research } \\
\text { organisations (generally } \\
\text { the lack of budgets and } \\
\text { sources of funding, } \\
\text { policy instruments or } \\
\text { procedures which could } \\
\text { be used to implement the } \\
\text { results of foresight } \\
\text { projects). The problem } \\
\text { of "ownership" with the } \\
\text { results and their } \\
\text { acceptance by } \\
\text { stakeholders not engaged } \\
\text { in the projects. }\end{array}$ & $\begin{array}{l}\text { priorities (funding is } \\
\text { based on a competitive } \\
\text { basis with a peer review } \\
\text { system including } \\
\text { international experts). } \\
\text { The programmes include } \\
\text { the description of the } \\
\text { logic of public } \\
\text { intervention and the } \\
\text { specific conditions for } \\
\text { funding research } \\
\text { projects, schedule, } \\
\text { budget, and risk } \\
\text { assessment to achieving } \\
\text { programme objectives. }\end{array}$ & $\begin{array}{l}\text { selection of proposals } \\
\text { (peer review system). }\end{array}$ \\
\hline Assessment & Poor & Relatively good & Relatively good \\
\hline $\begin{array}{l}\text { Monitoring and } \\
\text { evaluation } \\
\text { mechanisms }\end{array}$ & $\begin{array}{l}\text { The monitoring and } \\
\text { evaluation systems were } \\
\text { not well developed. } \\
\text { Evaluation of the } \\
\text { foresight projects were } \\
\text { carried out by the MSHE } \\
\text { in } 2011 \text { and by the } \\
\text { NCRD in } 2013 \text {. }\end{array}$ & $\begin{array}{l}\text { The programmes include } \\
\text { the monitoring and } \\
\text { evaluation system (in } \\
\text { each programme } \\
\text { evaluation ex-ante were } \\
\text { carried out). }\end{array}$ & $\begin{array}{l}\text { The programmes include } \\
\text { the monitoring an } \\
\text { evaluation system (in } \\
\text { each programme } \\
\text { evaluation ex-ante were } \\
\text { carried out). }\end{array}$ \\
\hline Assessment & Enough & Good & Good \\
\hline
\end{tabular}

Source: Own elaboration

with the implementation of their results through i.e. defining an appropriate policy mix. Such an example could be the case of taking advantage of foresight exercise in public procurement in Lombardia. It also requires more engagement and a better understanding of the benefits of foresight exercises from policymakers.

\section{Strategic Research and Development Programmes}

The mechanism introduced by the NRP, including the strategic research and development programmes, is the result of a learning process by public institutions and the experiences with previous initiatives introduced by the NFP and the NRDP. The NFP, NRDP and NRP are examples of a top-down approach which is the one-way direction process from the top level (the Ministry of Science or the Council of Ministers) down to the research performers. Surprisingly, research priorities have not changed substantially over the last 10 years and are very similar in these strategic documents. The main critics of the NRP mechanism (as well as the NFP and NRDP) is associated with the domination of the research community and minimal engagement of business representatives 
in selecting priorities (some argue that it is one of the reasons why the research priorities have remained the same).

From the perspective of entrepreneurs, the strategic research and development programmes are still more research- than business-driven and are better fitted to research than market needs. Not surprisingly, the pervasive performers of ordered projects and the strategic research and development programmes are research organisations. It is pointed out that the NRP rather constitutes the general list encompassing many broad research fields. The Council of the NCRD and these programmes are launched without a coherent strategic plan (Klincewicz 2014). On the other hand, the NFP, NRDP and NRP are an interesting example of the evolution of priority setting processes at governmental level. The growing role of the NCRD in this field reflects the trend observed in Western countries called agencyfication. The division between strategic and operative levels of priority setting is evident in the case of the NRP. The strategic document (the NRP) was prepared by the Ministry of Science and accepted by the Council of Ministers, but the strategic research and development programmes have been prepared by the Council of the NCRD and the NCRD.

\section{Sectoral Research Programmes}

Despite the short period since their introduction, sectoral research programmes seem to be a promising scheme and effective tool to mobilise stakeholders to identify research and development priorities. The advantage of this scheme is that it gives the leading role to stakeholders in the identification of research priorities. Sectoral programmes are also established on a more flexible basis than strategic research development programmes. The NCRD facilitates the process and helps companies to conduct the priority setting exercise. Sectoral research programmes represent the bottom-up approach driven by the enterprise and, thus, are more familiar with the idea of entrepreneurial discovery processes and the smart specialisation strategy. Such programmes are also interesting due to the role of government or governmental agency. The lead role is played by private sector representatives which initiates the process and prepares the research agenda draft, i.e. identifies the important research priorities from the perspective of entrepreneurs and users. The NCRD acts as facilitator which supports the activities of enterprises. Leadership is to some extent divided between private and public partners. It is worth noting that the NCRD is a relatively new agency, founded in 2007 and substantially reorganised in 2010 . During its short time of existence, the NCRD has established a reputation as being less-risk averse toward financing genuinely innovative projects. The NCRD applies flexible rules, accumulates expertise in collaboration with the business sector and adopts international best practice (Kapil et al. 2013). As a consequence, the NCRD acts rather like a venture agency which enables collaboration with the private sector in this field (this approach is also seen in other schemes implemented by the NCRD such as strategic research and development programmes). The initiative is called "the sectoral research programme", but the term "sectoral" is used here in a specific way. It is used 
in order to differentiate programmes at policy level and does not reflect the content of the programmes which consider innovation in the broader sense than the sectoral perspective. Sectoral research programmes are open to companies from different industrial sectors that can participate in finding solutions for problems identified in the research agenda. The scope of sectoral research programmes is based on the value-chain logic rather than strict sectoral/ industrial classification. Additionally, the reason for using in these contexts the term sectoral may be that in Polish, it indicates the leading role of business and industry. Nevertheless, the name of the scheme does not respond properly to the content of the programmes.

The overview of the evolution of the research system, and especially of the discussed activities, shows that the process of priority setting in Poland is rather the set of initiatives aiming at setting priorities for research and development. The NRP should be treated as the guide for the NCRD Council to establish strategic research and development programmes. Simultaneously, there has been established by the Ministry of Science and Higher Education or the NCRD (topdown approach) the thematic programmes dedicated to some specific fields such as the humanities, graphene or shale gas, which are not represented in the NRP (despite the fact that the priorities set out by the NRP are very broad). The sectoral research programmes (INNOLOT, INNOMED) refer to the NRP, but this link is quite general. They should be seen as an example of the bottom-up approach which precisely sets out the expectations and needs of entrepreneurs.

From the perspective of priority setting and stakeholder engagement, the evolution of the research system is still in progress. Nevertheless, the analysed initiatives could be the source of interesting and useful experience in this field. The important impact on this evolution will also include the concept of smart specialisation which privileges bottom-up and entrepreneurial activities in setting priorities for research and development.

\section{Appendix. The list of initiatives and activities selected to analysis in the article}

The National Centre for Research and Development:

1. BIOSTRATEG programme

2. STRATEGMED programme

3. Advanced Technologies for Research Generation

4. Interdisciplinary System for Interactive Scientific and Scientific Technical Information

5. Integrating System for Reducing Energy Consumption in the Maintenance of Buildings

6. Improving Work Safety in Mines

7. Technologies Supporting Development of Safe Nuclear Power Engineering

8. INNOLOT programme

9. INNOMED programme

10. Support for foresight projects (the activity 1.1.1 of the Operational Programme Innovative Economy) 
11. GRAF-TECH programme

12. Blue Gas-Polish Shale Gas programme

13. Defence and Security programmes and projects

The Ministry of Science and Higher Education :

14. National Leading Scientific Centre programme

15. Polish Roadmap for Research Infrastructure

16. National Programme for the Development of Humanities

The Ministry of Environment:

17. GEKON programme

18. GREEN-EVO programme

The other institutions:

19. Basis of Polish technologies (managed by: the Ministry of Economy, the Ministry of Science and Higher Education, the Data Processing Institute, the Patent Office of Republic of Poland)

Open Access This article is distributed under the terms of the Creative Commons Attribution License which permits any use, distribution, and reproduction in any medium, provided the original author(s) and the source are credited.

\section{References}

Arancegui, M.N., Querejeta, M.J.A., \& Montero, E.M. (2011). Smart specialisation strategies; the case of the Basque country. Orkestra Working Paper Series in Territorial Competitiveness. http://i3s.ec.europa.eu/ commitment/30/download/5256.html;i3sid=2x31TTzVBkpSqzhfJ4v1SLwW1kZJJsh2fJBpynkMGxYQ 1FYrnhTG!93932101. Accessed January 2014.

Cervantes, M., \& Keenan, M. (2010). Priority setting for public research: challenges and opportunities. OECD.

Chan, L., \& Daim, T. (2012). Exploring the impact of technology foresight studies on innovation: Case of BRIC countries. Special Issue: Politics, Democracy and Degrowth. doi:10.1016/j.futures.2012.03.002

Czaplicka-Kolarz, K., Stańczyk, K., \& Kapusta, K. (2009). Technology foresight for a visio of energy sector development In Poland till 2030. Delphi survey as an element of technology forecasting. Technological Forecasting \& Social Change, 76, 327-338.

Czaplicka-Kolarz, K., Bondaruk, J., Zawartka, P., Siodłak, Ł., Klimkiewicz, A., Kantor, M., Siwek-Skalny, A., Hamerla, A., Góral, R. (2011). Analiza końcowa. Badanie Delphi i konsultacje społeczne. http://www. mg.gov.pl/files/upload/17151/TOM_III_Delphi.pdf. Accessed January 2014.

Edler, J. (2011). Innovation in EU CEE: the role of demand-based policy. In S. Radosevic, \& A. Kaderabkova (Eds.), Challenges for European Innovation Policy (pp. 177-208). Cheltenham: Edward Elgar.

EU REGULATION (1303/2013/EU). Regulation of 17 December 2013 laying down common provisions on the European Regional Development Fund, the European Social Fund, the Cohesion Fund, the European Agricultural Fund for Rural Development and the European Maritime and Fisheries Fund and laying down general provisions on the European Regional Development Fund, the European Social Fund, the Cohesion Fund and the European Maritime and Fisheries Fund and repealing Council Regulation (EC) No $1083 / 2006$.

Foray, D., \& Goenaga, X. (2013). The goals of Smart Specialisation. JRC Scientific and Policy Reports: S3 Policy Brief Series, 1.

Foray, D., \& Rainoldi, A. (2013). Smart specialisation programmes and implementation. JRC Scientific and Policy Reports: S3 Policy Brief Series, 2.

Foray, D., David, P.A., \& Hall, B.H. (2009). Smart specialisation -the concept. Knowledge Economists Policy Brief, 9. 
Foray, D., David, P.A., \& Hall, B.H. (2011). Smart specialisation. From academic idea to political instrument, the surprising career of a concept and the difficulties involved in its implementation. MTEIWORKING PAPER 1.

Foray, D., Goddard, J., Geonaga, X., Landabaso, M., McCann, P., Morgan, K., Nauwelaers, C., \& OrtegaArgiles, R. (2012).Guide to research and innovation strategies for smart specialisation (RIS3).

Gassler, H., Polt, W., Schindler, J., Weber, M., Mahroum, S., Kubeczko, K., \& Keenan, M. (2004). Priorities in science and technology policy - an international comparison. Project report. http://www.rat-fte.at/tl_files/ uploads/Studien/04 JR_Priorities\%20in\%20S\&T\%20Policy.pdf. Accessed January 2014.

Gassler, H., Polt, W., \& Rammer, Ch. (2008). Priority setting in technology policy -historical development and recent trends. In C. Nauwelaers, \& R. Wintjes (Eds.), Innovation policy in Europe (pp. 203-224). Cheltenham:Edward Elgar.

Georghiou, L., \& Harper, J. C. (2011). From priority-setting to articulation of demand: foresight for research and innovation policy and strategy. Futures: Future-oriented Technology Analysis. doi:10.1016/j.futures. 2010.11.003.

Georghiou, L., \& Keenan, M. (2006). Evaluation of national foresight activities: assessing rationale, process and impact.Technological Forecasting and Social Change. doi:10.1016/j.techfore.2005.08.003.

Goldberg, I. (2004). Poland and the knowledge economy . Washington, DC: The World Bank.

Habegger, B. (2010). Strategic foresight in public policy; reviewing the experiences of the UK, Singapore and the Netherlands. Futures. doi:10.1016/j.futures.2009.08.002.

Jabłecka, J. (2009). Revolution and evolution in the organisation of public research funding in Poland between 1991 and 2007. In J. Jabłecka (Ed.), Public research funding. Research councils, funding instruments, evolution of the system in Poland. Warsaw.

Kapil, N., Piątkowski, M., Radwan, I., \& Gutierrez, J.J. (2013). Poland enterprise innovation support review: from catching up to moving ahead. The World Bank. http://www-wds.worldbank.org/external/default/ WDSContentServer/WDSP/IB/2013/02/14/000356161_20130214144748/Rendered/PDF/ 753250WP0P09660ATION0SUPPORT0REVIEW.pdf. Accessed January 2014.

Klincewicz, K. (2014). ERAWATCH Country Report 2012: Poland, Joint Research Centre. http://erawatch.jrc. ec.europa.eu/erawatch/export/sites/default/galleries/generic_files/file_0482.pdf. Accessed January 2014.

Kościelecki, P., Tokaj-Krzewska, A., Miller, A., \&Pander, W. (2011). Raport końcowy z badania pt. „ocena stanu realizacji 1 i 2 Priorytetu Programu Operacyjnego Innowacyjna Gospodarka w połowie okresu programowania. http://www.ewaluacja.gov.pl/Wyniki/Documents/midterm_1_2_priorytet_POIG_ 2012013.pdf. Accessed January 2014.

Kowalewski, O., \& Rybiński, K. (2011). The hidden transformation. Changing role of the state after the collapse of communism in Central and Eastern Europe. Oxford Review of Economic Policy, 27(3), (634-657).

Kozłowski, J. (2012). Priorytety w Nauce, Forum Akademickie, 9. https://forumakademickie.pl/fa/2012/09/ priorytety-w-nauce/\#. Accessed January 2014.

Martin, B.R. (2010a). Inside the public scientific system: changing modes of knowledge production. In R.E. Smits, S. Kuhlmann, \& P. Shapira (Eds.), The theory and practice of innovation policy. Edward Elgar. doi: $10.4337 / 9781849804424.00008$.

Martin, B. R. (2010b). The origins of the concept of foresight in science and technology: An insider's perspective. Technological Forecasting \& Social Change. doi:10.1016/j.techfore.2010.06.009.

McCann, P., \& Ortega-Argilés, R. (2011). Smart specialisation, regional growth and applications to EU Cohesion Policy, Economic Geography Working Paper. University of Groningen. http://i3s.ec.europa.eu/ commitment/30/download/5250.html;i3sid=Q116Tz8hQN6F0v0Jz3qW5yM7SJGLNMNlngv MJnrp0vjTwWqWMwxT!93932101. Accessed January 2014.

Meissner, D. (2012). Results and impact of national Foresight-studies. Futures. doi:10.1016/j.futures.2012.07.010.

Meske, W. (1998). Institutional transformation of S\&T systems in the European economies in transition: comparative analysis. WZB Discussion Paper, No P 98-403. http://econstor.eu/bitstream/10419/50919/1/ 268694508.pdf. Accessed January 2014.

MES (2005). The National Framework Programme. Rules, procedures and topics, The Ministry of Education and Science. Warsaw.

MSHE (2008). The National Research and Development Programme. The Ministry of Science and Higher Education. Warsaw.

MSHE (2011). The National Research Programme, Assumptions for the Science and Technology and Innovation Policy of the State. The Ministry of Science and Higher Education. Warsaw. http://www. nauka.gov.p1/g2/oryginal/2013_05/bd3c0cc119647877df39fb7eeb3163f5.pdf. Accessed January 2014.

Nazarko, J., Ejdys, J., Gudanowska, A., Kononiuk, A., Magruk, A., Nazarko, L., \& Prusiel, L. (2011). Badanie ewaluacyjne realizowanych w Polsce projektów foresight. www.nauka.gov.p1/g2/...05/ 797b80cfa5bcf19effd23a6ae71f0db2.pdf. Accessed January 2014. 
Nazarko, J., Glińska, U., Kononiuk, A., \& Nazarko, Ł. (2013). Sectoral foresight In Poland: thematic and methodological analysis. International Journal of Foresight and Innovation Policy. doi:10.1504/IJFIP. 2013.051759 .

NCRD (2013a). Description of the INNOLOT programme. version 26. http://www.ncbir.pl/gfx/ncbir/ userfiles/_public/programy_krajowe/innolot/2013-03-26_opis_programu_innolot-2.pdf. Accessed January 2014.

NCRD (2013b). Założenia programu sektorowego INNOMED. http://www.ncbir.pl/gfx/ncbir/userfiles/_ public/programy_krajowe/innomed/zalozenia programu_innomed.pdf. Accessed January 2014.

NIK (2002). Informacja o wynikach kontroli wydatkowania środków budżetowych na finansowanie (dofinansowanie) przez Komitet Badań Naukowych projektów badawczych podejmowanych na wniosek organów administracji rządowej. http://www.nik.gov.pl/kontrole/wyniki-kontroli-nik/pobierz,px_ 2002143.pdf,typ,k.pdf. Accessed January 2014.

OECD (2003). Priority setting: issues and recent trends . Paris.

OECD (2007). Policy mix for innovation in Poland: Key issues and recommendations. Warsaw.

Okoń-Horodyńska, E. (2007). Foresight - identification of science and technology priorities of economic development (the case of Poland). In K. Piech (Ed.), Knowledge and innovation processes in Central and East European economies, (pp. 164-168). Warsaw: Instytut Wiedzy i Innowacji.

Okoń-Horodyńska, E. (2009). Podstawowe Informacje o Programie i Metodzie. In Kowalewska, A. Głuszczyński, J., Zastosowanie metody Delphi w Narodowym Programie Foresight Polska 2020. Główne wyniki, doświadczenia i wnioski, (pp. 8-39). http://www.nauka.gov.pl/g2/oryginal/2013 05/ 2255ae5e6c6148711bd5366564b44cfa.pdf. Accessed January 2014.

Pbid Re-source and FUM (2009). Efekty wsparcia sfery badawczo-rozwojowej w SPO WKP w kontekście rozpoczęcia realizacji POIG. Pracownia badań i doradztwo Re-source, Fundacja Uniwersytetu im. A. Mickiewicza. www.ewaluacja.gov.p1/Wyniki/Documents/2_041.pdf. Accessed January 2014.

PPTL (2014). Strategia Badawcza Przemysłu Lotniczego 2012-2035. Polska Platforma Technologiczna Lotnictwa. http://www.pptl.p1/download/Z2Z4L3BwdGwvcGwvZGVmYXVsdF9ha3R1YWxub3Nja S82LzE5LzE/strategia_20140305.pdf. Accessed January 2014.

Radosevic, S. (1996). Restructuring of R\&D institutes in post-socialist economies: emerging patterns and issues. In A. Webster (Ed.), Building new basis for innovation: the transformation of R\&D system in PostSocialist States (pp. 8-30). Cambridge.

Rodrik, D. (2004). Industrial policy for the Twenty-First Century . Cambridge: Harvard University.

Rogut, A., \& Piasecki, B. (2011). Foresight methodology as a tool for elaboration of plans for sustainable management of water, energy, the environment and society . Ecohydrology and Hydrobiology. doi:10. 2478/v10104-011-0049-9.

Vecchiato, R., \& Roveda, C. (2014). Foresight for public procurement and regional policy; the case of Lombardy. Research Policy, doi:10.1016/j.respol.2013.11.003. 